\title{
A THEORY OF USER-FEE COMPETITION
}

\author{
Clemens Fuest \\ MARTIN KOLMAR \\ CESIFO WORKING PAPER NO. 1166 \\ CATEgORY 1: PUBliC FinANCE \\ MARCH 2004
}

An electronic version of the paper may be downloaded

- from the SSRN website:

www.SSRN.com

- from the CESifo website: www.CESifo.de 


\title{
A THEORY OF USER-FEE COMPETITION
}

\begin{abstract}
We develop a two-region model where the decentralized provision of spillover goods can be financed by means of taxes or user fees. In order to enforce the fees regions have to invest in exclusion. We show that a decentralized solution tends to be inefficient. There will be over-investment in exclusion and an underprovision of the spillover goods compared to a centralized solution. In addition the regions have strategic incentives to set user charges. If the regional spillover goods are substitutes user fees tend to be inefficiently low, whereas they tend to be inefficiently high if the spillover goods are complements.
\end{abstract}

JEL classification: D74, H41.

Keywords: public goods, club goods, user fees, fiscal federalism.

\author{
Clemens Fuest \\ University of Cologne \\ Meister Ekkehart-Str. 11 \\ $50937 \mathrm{Köln}$ \\ Germany \\ clemens.fuest@uni-koeln.de
}

\author{
Martin Kolmar \\ University of Mainz \\ Department of Law and Economics \\ Jakob Welder-Weg 4 \\ 55099 Mainz \\ Germany \\ kolmar@uni-mainz.de
}




\title{
1 Introduction
}

\author{
„A highway, a bridge, a navigable canal [...] may in most cases be both made \\ and maintained by a small toll upon the carriages which make use of them. [...] It seems \\ scarce possible to invent a more equitable way of maintaining such works. "
}

(Adam Smith, The Wealth of Nations.)

Economic integration creates pressures to reduce taxes on mobile tax bases. This forces governments to either reduce public expenditure or to raise revenue from other sources. One possibility is to levy higher taxes on immobile bases. Another possibility is that governments rely more on user-fee financing. In the literature, the possibility that fiscal competition may lead to an increasing tax burden on immobile tax bases and inefficient levels of public-goods supply has received a lot of attention ${ }^{1}$ whereas the possibility of more user-fee financing has been neglected. This may be due to the fact that standard models of fiscal competition usually assume that there is a sharp distinction between private and public goods. Public goods are characterized by non-excludability, so that user-fee financing is impossible, whereas those goods where exclusion is possible can be provided by private markets right away. This view of the borderline between public and private tasks neglects that, for many public services, exclusion is possible but costly. These costs may be interpreted as the costs of using the market mechanism. Highways are a very good example. In some countries like e.g. Germany, highways are financed entirely via taxes and everybody may use them without paying user fees. Currently, though, the government tries to introduce user fees. In other countries like e.g. Italy or France, user fees are levied on highways. Of course, user fees require investment in exclusion. Depending on the exclusion technology and the level of investment, exclusion may or may not be perfect.

Next to declining tax revenues from mobile bases, there is a second potential reason to increase user-fee financing. More economic integration is also likely to imply that publicly provided services are increasingly consumed by residents of other

\footnotetext{
${ }^{1}$ The literaure on capital-tax competition is huge. See Wilson (1999), Janeba and Schjelderup (2002) and Fuest et al. (2003) for recent surveys.
} 
jurisdictions. In the presence of spillovers of this kind, user fees offer a possibility of partially 'exporting' the burden of financing the service.

It is the purpose of this paper to analyze the effect of fiscal competition on the role of user-fee financing. We consider a model of inter-jurisdictional competition where governments supply a public service to both, domestic residents as well as foreigners. Governments may levy user fees, but this is possible only if the government spends resources on exclusion. In this framework, we ask how fiscal competition affects the choice between tax and user-fee financing, and we investigate whether uncoordinated tax and user-fee policies are efficient for the economy as a whole.

Our analysis leads to the following main results. In a coordinated optimum the optimal relationship between tax and user-fee financing of spillover goods is determined by the comparison between the welfare costs of distortionary taxation and the costs of using the market mechanism. A market mechanism is extended to the point where the marginal costs of an increase in exclusion is equal to the marginal benefits of exclusion. The marginal benefits are determined by the reduction of the distortion created by taxation. In a world with lump-sum taxation and costless enforcement of user fees the best way to finance the provision of spillover goods is indeterminate: user fees act as Lindahl prices, and every combination of tax and user-fee financing is first-best efficient.

Decentralization of decision making changes this economic rationale in two important aspects. First, the provision of spillover goods by means of taxation would be inefficient even if the tax were non-distortionary. The reason is that even with a lump-sum tax a national government would not internalize the spillover created by the supply of the spillover good. Lindahl prices are then a mechanism that induces the internalization of this externality. Second, the incentive to use user fees changes compared to a centralized solution. A national authority setting user fees and associated enforcement policies for foreigners neglects the direct effect of an increase in user fees and enforcement on foreign utility. Hence, it will set the price as to maximize revenues, not as to internalize externalities. This strategic role of prices is in conflict with their potential allocative role to act as Lindahl prices.

Given that there are various externalities between countries, there is a potential 
for welfare-enhancing policy coordination between the two countries. The direction of this coordination, however, is ambiguous as far as user fees are concerned. Whether user fees are too high or too low under decentralization depends on whether domestic and foreign spillover goods are substitutes or complements. This finding is different from the standard 'race to the bottom'-finding in the tax-competition literature. The reason for this difference is that the tax-competition literature starts from the quite natural assumption that from the point of view of capital investors both countries are substitutes, which creates an incentive to strategically reduce tax rates. This assumption is no longer natural for the case of different spillover goods. Highways, for example, can either be substitutes or complements from the point of view of the users. If they are substitutes the same logic as in the tax-competition literature explains why user fees are set inefficiently low. For the case of complementary spillover goods, however, countries may engage in a race to the top ending up with inefficiently high user fees. However, irrespective of the degree of complementarity, the provision of the spillover good is inefficiently low whereas exclusion investments are inefficiently high in a decentralized equilibrium.

Despite the fact that to our best knowledge competition in user fees has not been analyzed in the literature so far, our analysis builds on three different strands of the literature. Our approach is related to the vast literature on tax and more generally systems competition (Sinn 2003) that focuses on the inefficiencies of decentralized decision making in integrated markets. The classic papers in the field of capitaltax competition are Bond and Samuelson (1989), Bucovetsky (1991), Bucovetsky and Wilson (1991), and Wilson (1991). The problem of tax versus fee financing of non-rival but excludable public goods is analyzed in Fraser (1996), Brito and Oakland (1997), and Janeba and Swope (2001). These papers identify different types of costs of tax and fee mechanisms depending on the political mechanism, the market structure, and the ability to discriminate prices. These papers remain in the tradition that assumes an exogenous distinction between excludable and non-excludable goods. The idea that exclusion is a costly economic activity is borrowed from the literature on optimal law enforcement, see for example Clotfelter $(1977,78)$ and the excellent survey by Polinsky and Shavell (2000) for the case of rival goods, and 
Laux-Mieselbach (1988) for the case of non-rival goods. However, none of these papers analyzes exclusion and price setting in integrated markets.

The paper proceeds as follows. In Section 2 we present the model. In Section 3 we continue with the analysis of the centralized solution. Section 4 is devoted to the analysis of decentralized decision making and the analysis of efficiency-enhancing policy coordinations. In addition we demonstrate the implications of our model for the special case of spillover goods that are perfect substitutes. Section 5 concludes.

\section{The model}

Economy and governments: We consider a standard static tax-competition model. An economy is divided into 2 regions, $i, j$. Together they form a union with perfectly integrated capital and goods markets. For simplicity we assume that every region is populated by a representative individual and has a local government that maximizes the utility of the regional resident. The government provides two goods. The first is a local public good whose quantity is denoted by $g^{i}$. This good only benefits domestic citizens and exclusion is impossible. The second one is a non-rival good which has the physical quality to also benefit foreigners and for which exclusion is possible but costly. The quantity of the second good is denoted by $c_{i S}$. For simplicity the production of the two goods is linear in expenditures. In order to finance its activities for example region $i$ can use a (source-based) tax on capital income, $t^{i}$, and it can levy user fees, $p_{i}^{i}, p_{j}^{i}$, per unit of the spillover good demanded by domestic and foreign users, $c_{i D}^{i}, c_{j D}^{i}$. Since exclusion with respect to $g^{i}$ is impossible, no user fees can be levied for $g^{i}$. Here and in the following, analogous conditions hold and analogous notation is used for region $j$.

As mentioned in the introduction, exclusion in our model is a costly activity. If the government does not invest in exclusion, individuals will free ride on the supply of the public good $c_{i S}$, and the government has to rely on capital-tax revenues in order to finance the good. Investment in exclusion allows it to finance the spillover goods by means of user fees. We assume that the enforcement of user fees levied by government $i$ and paid by residents of $i$ and $j$ incurs an (endogenous) cost $d_{i}^{i}$, 
$d_{j}^{i}$ (defense), for example for the patrolling of police cars on or the installation of toll booths or electronic toll-collecting systems along the streets. These defensive investments influence the degree of exclusion as follows. Given the investments $d_{i}^{i}, d_{j}^{i}$ we denote by $\pi_{i}^{i}=\pi\left(d_{i}^{i}\right), \pi_{j}^{i}=\pi\left(d_{j}^{i}\right)$ the fraction of the total supply of the spillover good $c_{i P}$ that is successfully defended against free riding. Analogously, $\left(1-\pi_{i}^{i}\right)$, $\left(1-\pi_{j}^{i}\right)$ are is the fractions of the spillover good for which users are successful in free-riding. The functions $\pi_{i}^{i}, \pi_{j}^{i}$ represent the technologies of exclusion. It is assumed that they are continuously differentiable and have the following properties:

$$
\frac{\partial \pi_{i}^{i}}{\partial d_{i}^{i}} \geq 0, \quad \frac{\partial^{2} \pi_{i}^{i}}{\partial\left(d_{i}^{i}\right)^{2}} \leq 0, \quad \lim _{d_{i}^{i} \rightarrow \infty} \pi_{i}^{i}=1 .
$$

Given these specifications, the budget constraint of government $i$ is

$$
k^{i} t^{i}+p_{i}^{i} c_{i D}^{i}+p_{j}^{i} c_{j D}^{i}=c_{S}^{i}+d_{i}^{i}+d_{j}^{i}+g^{i} .
$$

The left-hand side of the equation measures total revenues of the region. They include capital-tax revenues that are equal to the capital-tax rate times the capital stock employed in country $i$, and the total payment of user fees that are equal to the sum of user-fees times spillover-good demand. The right-hand side of the equation measures total expenditures of the region. They include the expenditures for the supply of the spillover good, the expenditures for the enforcement of the user fees and expenditures for the public good $g^{i}$.

Individuals: The representative individual in region $i$ derives utility from the consumption of a private good, $x^{i}$, from consumption of the local public good, $g^{i}$, and from the consumption of the spillover goods provided by its region of origin and the other regions, $c_{i S}, c_{j S}$. W.l.o.g we assume that the price of the private good is normalized to be equal to one. The utility functions of the representative individuals are given by $u^{i}=u\left(x^{i}, c_{i}^{i}, c_{i}^{j}, g^{i}\right)$ which is assumed to be strictly quasi-concave and twice continuously differentiable in $\mathbb{R}_{4}^{++}$. In the extreme case it may be that $\partial u_{i} / \partial c_{i}^{j}=0$ if there is no spillover. The individual is endowed with a quantity $\bar{k}_{i}$ of a capital good.

Denote by $c_{i}^{i}, c_{j}^{i}$ the total quantity of spillover good $i, j$ consumed by individual $i .\left(1-\pi_{i}^{i}\right) c_{S}^{i},\left(1-\pi_{j}^{i}\right) c_{S}^{j}$ are the quantities consumed without paying user fees 
(free-rider quantities), and $c_{i D}^{i}, c_{i D}^{j}$ are the quantities consumed with paying user fees (purchased quantity). Given profit income, $P^{i}$, given the gross capital-market interest rate, $r$, the tax rate, $t^{i}$, and user fees, $p_{i}^{i}, p_{i}^{j}$, the budget and consumption constraints of a resident of region $i$ are

$$
\begin{aligned}
c_{i}^{i} & =\left(1-\pi_{i}^{i}\right) c_{S}^{i}+c_{i D}^{i}, \\
c_{i}^{j} & =\left(1-\pi_{i}^{j}\right) c_{S}^{j}+c_{i D}^{j}, \\
P^{i}+r \bar{k}_{i} & =x^{i}+p_{i}^{i} c_{i D}^{i}+p_{i}^{j} c_{i D}^{j} .
\end{aligned}
$$

The first two of constraints specify that the total quantity of the public goods consumed is the sum of the free-rider and the purchased quantity. The left-hand side of the last constraint is the net-total income of the individual. It is the sum of the profit income and the net capital income. The right-hand side measures total expenditures. They are the sum of expenditures for the private and spillover goods.

Firms: Production in each country takes place under conditions of perfect competition with a strictly concave production function $y^{i}=f\left(k^{i}\right)$, which relates output of the consumption good to the amount of (physical) capital investment, $k^{i}$. In order to simplify the analysis we assume that firms in country $i$ are exclusively owned by resident $i$ and vice versa. The profit income $P^{i}$ is then equal to the profit of a representative firm in region $i$, which is equal to

$$
P^{i}=f\left(k^{i}\right)-\left(r+t^{i}\right) k^{i}
$$

Sequence of events: We consider a two-stage game. In the decentralized version of the model (Section 4), every region non-cooperatively determines its tax rates, defensive activities, spillover-goods supply, and user fees, $T^{i}=\left\{t^{i}, d_{i}^{i}, d_{j}^{i}, c_{S}^{i}, p_{i}^{i}, p_{j}^{i}, g^{i}\right\}$, subject to the constraints that the government-budget constraint is fulfilled and that demand does not exceed maximum supply, $\pi_{i}^{i} c_{S}^{i} \geq c_{i D}^{i}, \pi_{j}^{i} c_{S}^{i} \geq c_{j D}^{i}$, at stage 1 . In order to characterize the second-best efficient benchmark we also calculate the solution of a centralized government that chooses $\left\{T^{i}, T^{j}\right\}$ under the same constraints at stage 1 (Section 3). A comparison of both solutions allows to identify the types of externalities existing with decentralized decision making, and thereby the sources of inefficiencies. 
Irrespective of the decentralized or centralized solution of stage 1, individuals maximize their utility by the choice of capital demand, $k^{i}, k^{j}$, the demand of the private good, $x^{i}, x^{j}$, and the demand of the spillover goods, $c_{i D}^{i}, c_{i D}^{j}, c_{j D}^{i}, c_{j D}^{j}$, at stage 2 . The game is solved by backwards induction.

Stage 2: The solution of the individual maximization problem at stage 2 is independent of the institutional structure at stage 1 and can be written as follows:

$$
\begin{array}{lll}
\max _{c_{i D}^{i}, c_{j D}^{i}, x^{i}, k^{i}} u\left(c_{i}^{i}, c_{j}^{i}, x^{i}, g^{i}\right) & \text { s.t. } & x^{i}=P^{i}+\tau^{i}+r K^{i}-p_{i}^{i} c_{i D}^{i}-p_{i}^{j} c_{i D}^{j} \\
& \wedge & c_{j}^{i}=\left(1-\pi\left(d_{i}^{j}\right)\right) c_{j S}+c_{i D}^{j}, \\
& \wedge & c_{i}^{i}=\left(1-\pi\left(d_{i}^{i}\right)\right) c_{i S}+c_{i D}^{i}, \\
& \wedge & P^{i}=f\left(k^{i}\right)-\left(r+t^{i}\right) k^{i},
\end{array}
$$

Inserting constraints 2-4 into constraint 1 and the objective function, and denoting by $\lambda^{i}$ the Lagrange multiplier on the remaining constraint, the individual optimum is characterized by the following first-order conditions (in order to have a lean notation the additional subscript denotes a partial derivative with respect to the denoted variable):

$$
\begin{array}{ll}
x^{i}: & u_{x}^{i}-\lambda^{i}=0, \\
c_{i D}^{i}: & u_{c_{i}^{i}}-\lambda^{i} p_{i}^{i} \leq 0 \quad \wedge \quad c_{i D}^{i} \geq 0, \\
c_{i D}^{j}: & u_{c_{i}^{j}}-\lambda^{i} p_{i}^{j} \leq 0 \quad \wedge \quad c_{j D}^{i} \geq 0, \\
k^{i}: & f_{k^{i}}\left(k^{i}\right)-\left(r+t^{i}\right)=0 .
\end{array}
$$

The above conditions imply that

$$
\frac{u_{i c}^{i}}{u_{x}^{i}}=p_{i}^{i}, \quad \frac{u_{i c}^{j}}{u_{x}^{i}}=p_{i}^{j}
$$

if $c_{i D}^{i}>0$ and $c_{i D}^{j}>0$ : user fees are equal to the marginal rate of substitution as long as the demand for the spillover goods is positive. This property will turn out to be crucial for an understanding of the solution of the government problem.

The solution of the household's maximization problem gives rise to demand functions $c_{i D}^{i}\left(p_{i}^{i}, p_{i}^{j}, d_{i}^{i}, d_{i}^{j}, c_{S}^{i}, c_{S}^{j}, t^{i}, r, g^{i}\right), \quad c_{i D}^{j}\left(p_{i}^{i}, p_{i}^{j}, d_{i}^{i}, d_{i}^{j}, c_{S}^{i}, c_{S}^{j}, t^{i}, r, g^{i}\right)$, 
$x^{i}\left(p_{i}^{i}, p_{i}^{j}, d_{i}^{i}, d_{i}^{j}, c_{S}^{i}, c_{S}^{j}, t^{i}, r, g^{i}\right), k^{i}\left(t^{i}, r\right)$, and an indirect utility function $v^{i}=$ $V^{i}\left(p_{i}^{i}, p_{i}^{j}, d_{i}^{i}, d_{i}^{j}, c_{S}^{i}, c_{S}^{j}, t^{i}, r, g^{i}\right)$.

The qualitative results of our analysis hold for general utility functions, However, in order to facilitate the analysis, we assume that the utility function is quasi linear in the following,

$$
u\left(c_{i}^{i}, c_{j}^{i}, x^{i}, g^{i}\right)=m\left(c_{i}^{i}, c_{j}^{i}\right)+x^{i}+h\left(g^{i}\right) .
$$

In this case, the Envelope theorem allows to calculate the following effects:

$$
\begin{aligned}
& v_{c_{i S}}^{i}=\left(1-\pi\left(d_{i}^{i}\right)\right) u_{c}^{i}, \quad v_{d_{i}^{i}}^{i}=-c_{i S} u_{c}^{i} \pi_{i d}^{i}, \quad v_{p_{i}^{i}}^{i}=-c_{i D}^{i} \lambda^{i}, \quad v_{t^{i}}^{i}=-k^{i} \lambda^{i}, \\
& v_{c_{j S}}^{i}=\left(1-\pi\left(d_{i}^{j}\right)\right) u_{i c}^{j}, \quad v_{d_{i}^{j}}^{i}=-c_{i S} u_{i c}^{j} \pi_{i d}^{j}, \quad v_{p_{i}^{j}}^{i}=-c_{i D}^{j} \lambda^{i}, \quad v_{t^{j}}^{i}=0, \quad v_{g^{i}}^{i}=h^{\prime} .
\end{aligned}
$$

In addition the following comparative-static results hold for an interior solution:

$$
\begin{aligned}
& \frac{\partial c_{i D}^{i}}{\partial c_{S}^{i}}=-\left(1-\pi\left(d_{i}^{i}\right)\right)<0, \quad \frac{\partial c_{i D}^{i}}{\partial c_{S}^{j}}=\frac{\partial c_{i D}^{i}}{\partial d_{i}^{j}}=0, \frac{\partial c_{j D}^{i}}{\partial c_{S}^{i}}=-\left(1-\pi\left(d_{j}^{i}\right)\right)<0, \\
& \frac{\partial c_{i D}^{i}}{\partial d_{i}^{i}}=c_{S}^{i} \pi_{i d}^{i}>0, \quad \frac{\partial c_{i D}^{j}}{\partial d_{i}^{j}}=c_{S}^{j} \pi_{i d}^{j}>0, \quad \frac{\partial c_{i D}^{j}}{\partial d_{i}^{i}}=\frac{\partial c_{i D}^{j}}{\partial c_{S}^{i}}=0, \\
& \frac{\partial c_{i D}^{i}}{\partial t^{i}}=0, \quad \frac{\partial c_{i D}^{i}}{\partial p_{i}^{i}}<0, \quad \frac{\partial c_{i D}^{i}}{\partial p_{i}^{j}}>0 \Leftarrow g_{c_{i}^{i} c_{i}^{j}}\left(c_{i}^{i}, c_{j}^{i}\right)>0 .
\end{aligned}
$$

\section{Coordinated utility maximization}

We start the discussion with the solution to the joint utility-maximization problem in order to characterize the second-best efficient policies. This allows us to identify the source of externalities of a decentralized solution. We assume that a (utilitarian) centralized planner faces the same instrumental constraints as the regional governments, and that he maximizes the sum of both regions' indirect utility functions subject to the two budget constraints. We include the regional budget constraints as two separate constraints in order to make sure that the optimum is not characterized by inter-regional transfers that would not be replicated by regional planners because they would be purely redistributive. In addition to the budget constraints, we have to take into account that private demand for the spillover good cannot ex- 
ceed supply in equilibrium. ${ }^{2}$ For country $i$ this requires $\pi_{i}^{i} c_{S}^{i} \geq c_{i D}^{i}$ and $\pi_{j}^{i} c_{S}^{i} \geq c_{j D}^{i}$. The constraints for country $j$ are analogous.

The Lagrangean of the coordinated problem can be written as:

$$
\begin{aligned}
\mathcal{L}^{c}= & V^{i}\left(p_{i}^{i}, p_{i}^{j}, d_{i}^{i}, d_{i}^{j}, c_{S}^{i}, c_{S}^{j}, t^{i}, r, g^{i}\right)+V^{j}\left(p_{j}^{j}, p_{i}^{i}, d_{j}^{j}, d_{j}^{i}, c_{S}^{j}, c_{S}^{i}, t^{j}, r, g^{j}\right) \\
& +\mu^{i}\left[t^{i} k^{i}+p_{i}^{i} c_{i D}^{i}+p_{j}^{i} c_{j D}^{i}-d_{i}^{i}-d_{j}^{i}-c_{S}^{i}-g^{i}\right] \\
& +\mu^{j}\left[t^{j} k^{j}+p_{j}^{j} c_{j D}^{j}+p_{i}^{j} c_{i D}^{j}-d_{j}^{j}-d_{i}^{j}-c_{S}^{j}-g^{j}\right] \\
& +\gamma_{i}^{i}\left[\pi_{i}^{i} c_{S}^{i}-c_{i D}^{i}\right]+\gamma_{j}^{i}\left[\pi_{j}^{i} c_{S}^{i}-c_{j D}^{i}\right] \\
& +\gamma_{j}^{j}\left[\pi_{j}^{j} c_{S}^{j}-c_{j D}^{j}\right]+\gamma_{i}^{j}\left[\pi_{i}^{j} c_{S}^{j}-c_{i D}^{j}\right] .
\end{aligned}
$$

where $\mu^{i}, \mu^{j}, \gamma_{i}^{i}, \gamma_{i}^{j}, \gamma_{j}^{j}, \gamma_{j}^{i}$ are the Lagrange multipliers. After some rearrangements, the derivatives of the Lagrangean with respect to the policy parameters for country $i$ are as follows:

$$
\begin{aligned}
g^{i}: & h^{\prime}-\mu^{i}, \\
t^{i}: & -\lambda^{i} k^{i}+\mu^{i}\left(k^{i}+t^{i} \frac{\partial k^{i}}{\partial t^{i}}\right)+\mu^{j} t^{j} \frac{\partial k^{j}}{\partial t^{i}}, \\
p_{i}^{i}: & \left(1-\frac{\lambda^{i}}{\mu^{i}}\right) c_{i D}^{i}+\left(p_{i}^{i}-\frac{\gamma_{i}^{i}}{\mu^{i}}\right) \frac{\partial c_{i D}^{i}}{\partial p_{i}^{i}}+\left(\frac{\mu^{j}}{\mu^{i}} p_{i}^{j}-\frac{\gamma_{i}^{j}}{\mu^{i}}\right) \frac{\partial c_{i D}^{j}}{\partial p_{i}^{i}}, \\
p_{j}^{i}: & \left(1-\frac{\lambda^{j}}{\mu^{i}}\right) c_{j D}^{i}+\left(p_{j}^{i}-\frac{\gamma_{j}^{i}}{\mu^{i}}\right) \frac{\partial c_{j D}^{i}}{\partial p_{j}^{i}}+\left(\frac{\mu^{j}}{\mu^{i}} p_{j}^{j}-\frac{\gamma_{j}^{j}}{\mu^{i}}\right) \frac{\partial c_{j D}^{j}}{\partial p_{j}^{i}}, \\
c_{S}^{i}: & \left.\left(1-\pi_{i}^{i}\right) \frac{u_{c_{i}^{i}}}{\mu^{i}}+\pi_{i}^{i} \gamma_{i}^{i}\right)+\left(\left(1-\pi_{j}^{i}\right) \frac{u_{c_{j}^{i}}}{\mu^{i}}+\pi_{j}^{i} \frac{\gamma_{j}^{i}}{\mu^{i}}\right)+p_{i}^{i} \frac{\partial c_{i D}^{i}}{\partial c_{S}^{i}}+p_{j}^{i} \frac{\partial c_{j D}^{i}}{\partial c_{S}^{i}}-1, \\
d_{i}^{i}: & \left(\frac{\gamma_{i}^{i}}{\mu^{i}}-\frac{u_{c_{i}^{i}}}{\mu^{i}}\right) \pi_{i d}^{i} c_{S}^{i}+\left(p_{i}^{i}-\frac{\gamma_{i}^{i}}{\mu^{i}}\right) \frac{\partial c_{i D}^{i}}{\partial d_{i}^{i}}-1, \\
d_{j}^{i}: & \left(\frac{\gamma_{j}^{i}}{\mu^{i}}-\frac{u_{c_{i}^{j}}}{\mu^{i}}\right) \pi_{i d}^{j} c_{S}^{i}+\left(p_{j}^{i}-\frac{\gamma_{j}^{i}}{\mu^{i}}\right) \frac{\partial c_{j D}^{i}}{\partial d_{j}^{i}}-1,
\end{aligned}
$$

${ }^{2}$ If planned demand exceeds supply, a rationing equilibrium arises and realized demand is given by supply. We ignore rationing equilibria because, if there were rationing, the government can always reduce exclusion until rationing disappears. A reduction in exclusion, however, reduces the total quantity of funds necessary, and thereby increases utility. By the same token, a supply of the spillover good that is smaller than the maximum supply defined by the no-free-rider quantity $\pi_{m}^{n} s_{S}^{n}, m, n=i, j$, can never be optimal because the planner can again reduce exclusion and thereby reduce the total funds necessary. 
where we have used (5) - (8) and (9). The results for the policy variables chosen by country $j$ are analogous. Note that the Lagrange multipliers have have a straightforward economic interpretation: $\mu^{i}$ and $\mu^{j}$ measure the increase in utility resulting from an exogenous increase in government revenues. They are equal to the marginal utility of the private good, $\lambda^{i}$ and $\lambda^{j}$, if the first-best can be implemented. $\gamma_{i}^{i}, \gamma_{i}^{j}$, $\gamma_{j}^{j}$, and $\gamma_{j}^{i}$ measure the increase in utility resulting from an exogenous increase in the supply of the spillover good.

Consider first the welfare effects of spending resources on exclusion. Using 9, and $u_{i c}^{i} / \lambda^{i}=p_{i}^{i}$ equation (16) boils down to

$$
d_{i}^{i}:-\frac{u_{i c}^{i}}{\mu^{i}} \pi_{i d}^{i} c_{S}^{i}+\frac{u_{i c}^{i}}{\lambda^{i}} \pi_{i d}^{i} c_{S}^{i}-1
$$

The first term of equation 18 captures the utility loss for free riders caused by more exclusion. The second term reflects that more exclusion investment increases market demand for the spillover good, which leads to more user fee revenue. The third term represents the direct costs of increasing exclusion investment. The interpretation of 17 is analogous. Equation 18 shows that, for the economy as a whole, spending resources on exclusion can only be optimal if the first-best exceeds the second-best marginal rate of substitution of the purchased quantity. This is usually the case if the government has to finance its expenditure via distortionary taxes and/or exclusion is imperfect.

In this case, it may be socially desirable to exclude agents from free riding because this induces them to increase their private demand for the good and pay user fees. In contrast, if a nondistortionary source of finance is available, it is never optimal to spend resources on exclusion. Given the assumptions of our model, the union as a whole does have access to such a nondistortionary tax. Since the capital supply to the union is assumed to be given, we have $k^{j}=\bar{k}^{i}+\bar{k}^{j}-k^{i}$, which implies

$$
\frac{\partial k^{i}}{\partial t^{i}}=-\frac{\partial k^{j}}{\partial t^{i}} .
$$

It follows from (12) that $\lambda^{i}=\mu^{i}$, which reflects that the capital tax is effectively a lump-sum tax. 
With a lump-sum tax on capital, (16) and (17) imply that it cannot be optimal to spend resources on exclusion, i.e. $d_{i}^{i}=d_{j}^{i}=0$ and $\pi_{i}^{i}, \pi_{j}^{i}=0$. It immediately follows that all user fees are zero and that the marginal utility of an exogenous increase in the supply of the spillover goods, $\gamma_{i}^{i}$ etc, is zero. Hence, (15) simplifies to

$$
\frac{u_{c_{i}^{i}}}{\lambda^{i}}+\frac{u_{c_{i}^{j}}}{\lambda^{j}}=1
$$

i.e. the supply of the spillover good satisfies the Samuelson condition. A role for user fees only arises if taxes are distortionary or exclusion is costless. In the latter case, the first-best equilibrium can also be implemented by means of user fees. To see this, assume for the sake of the argument that $\pi_{i}^{i}(0)=\pi_{j}^{i}(0)=1$. For $\pi_{i}^{i}=1$ we get $\gamma_{i}^{i}=u_{c_{i}^{i}}$ etc. at the first best. Given that $\lambda^{i}=\mu^{i}$, (15) implies Lindahl pricing, i.e. $p_{i}^{i}+p_{j}^{i}=1$.

In general, however, (15) defines a complicated 'modified' Samuelson condition: the first two bracketed terms measure the sum of a composed marginal rate of substitution between spillover and private goods consumption. This composed marginal rate of substitution consists of the linear combination of (i) the marginal rate of substitution resulting from free riding and (ii) the marginal rate of substitution resulting from purchasing. Accordingly, both rates are weighted according to the corresponding fractions. The third and fourth terms measure the public-revenue effect resulting from an increase in the production of the spillover good: an increase in the total quantity will influence the demand of the spillover good because it increases the free-rider quantity. Last not least, the fifth effect $(-1)$ measures the marginal rate of transformation.

The optimal user-fee policy is defined by (13) and (14). An optimal user fee balances three effects. The first term in (13) and (14) is a measure for the marginal costs of public funds. It is larger then zero if capital taxes are distortionary and exclusion is costly in general. If the demand for the spillover goods was constant, the condition would imply that user fees are increased as long as the marginal costs of public funds are positive, $\lambda_{i}<\mu_{i}$ etc. The second and third effect, however, incorporate the reaction of spillover-goods demand to changes in user fees. These effects are weighted by the deviation between the first and second best marginal rate of substitution. 


\section{Decentralized utility maximization}

We now assume that each country sets its policy instruments simultaneously and non-cooperatively. A decentralized Nash equilibrium is a vector $\left\{T^{i N}, T^{j N}\right\}$ such that both countries maximize utility given the policy parameters of the other country.

The Lagrangean of the decentralized problem of country $i$ can be written as:

$$
\begin{aligned}
\mathcal{L}^{c}= & V^{i}\left(p_{i}^{i}, p_{i}^{j}, d_{i}^{i}, d_{i}^{j}, c_{S}^{i}, c_{S}^{j}, t^{i}, r, g^{i}\right) \\
& +\mu^{i}\left[t^{i} k^{i}+p_{i}^{i} c_{i D}^{i}+p_{j}^{i} c_{j D}^{i}-d_{i}^{i}-d_{j}^{i}-c_{S}^{i}\right] \\
& +\gamma_{i}^{i}\left[\pi_{i}^{i} c_{S}^{i}-c_{i D}^{i}\right]+\gamma_{j}^{i}\left[\pi_{j}^{i} c_{S}^{i}-c_{j D}^{i}\right] .
\end{aligned}
$$

The derivatives of the Lagrangean with respect to the policy parameters are as follows:

$$
\begin{aligned}
g^{i}: & h^{\prime}-\mu^{i} \\
t^{i}: & -\lambda^{i} k^{i}+\mu^{i}\left(k^{i}+t^{i} \frac{\partial k^{i}}{\partial t^{i}}\right), \\
p_{i}^{i}: & \left(1-\frac{\lambda^{i}}{\mu^{i}}\right) c_{i D}^{i}+\left(p_{i}^{i}-\frac{\gamma_{i}^{i}}{\mu^{i}}\right) \frac{\partial c_{i D}^{i}}{\partial p_{i}^{i}}, \\
p_{j}^{i}: & c_{j D}^{i}+\left(p_{j}^{i}-\frac{\gamma_{j}^{i}}{\mu^{i}}\right) \frac{\partial c_{j D}^{i}}{\partial p_{j}^{i}}, \\
c_{S}^{i}: & \left(\left(1-\pi_{i}^{i}\right) \frac{u_{c_{i}^{i}}}{\mu^{i}}+\pi_{i}^{i} \frac{\gamma_{i}^{i}}{\mu^{i}}\right)+\frac{\gamma_{j}^{i}}{\mu^{i}}+p_{i}^{i} \frac{\partial c_{i D}^{i}}{\partial c_{S}^{i}}+p_{j}^{i} \frac{\partial c_{j D}^{i}}{\partial c_{S}^{i}}-1, \\
d_{i}^{i}: & \left(\frac{\gamma_{i}^{i}}{\mu^{i}}-\frac{u_{c_{i}^{i}}}{\mu^{i}}\right) \pi_{i d}^{i} c_{S}^{i}+\left(p_{i}^{i}-\frac{\gamma_{i}^{i}}{\mu^{i}}\right) \frac{\partial c_{i D}^{i}}{\partial d_{i}^{i}}-1, \\
d_{j}^{i}: & \left(p_{j}^{i}-\frac{\gamma_{j}^{i}}{\mu^{i}}\right) \frac{\partial c_{j D}^{i}}{\partial d_{j}^{i}}-1+\frac{\gamma_{j}^{i}}{\mu^{i}} \pi_{i d^{j}}^{i} c_{S}^{i} .
\end{aligned}
$$

The non-cooperative policy differs from the coordinated policy in several ways. Firstly, capital taxes are no longer considered to be non-distortionary because, given the level of foreign taxes, an increase in domestic taxes in country $i$ induces a capital flow to country $j$ whose welfare effects are not internalized by country $i$. Hence, (21) implies $\lambda^{i}-\mu^{i}<0$ for $t^{i}>0$. A taxation of capital according to the source principle 
ceteris paribus implies inefficiently low tax rates in equilibrium. This is the type of capital-tax competition well known from the literature.

Secondly, user fees and exclusion investments related to foreigners are set to each region's revenue-maximizing level (equations (23) and (26)). This reflects that governments neither internalize the direct effect on the utility of foreign citizens nor the effect on foreign revenues when choosing $p_{j}^{i}$ and $d_{j}^{i}$.

Thirdly, compared to the situation with an exogenous interregional capital stock the fact that taxes are distortionary may also induce the government to invest resources in order to exclude of domestic citizens from use of the spillover good (equation (25)) in order to finance part of the public and spillover good by means of user fees. It is important to note that the regional incentives to set user fees on domestic citizens is also diluted by an externality because the associated change in demand has a revenue effect in the foreign region.

Consider finally the condition for the supply of the spillover good, (24). Compared to the centralized solution it follows that the tax-financed free-rider fraction of the spillover good consumed by foreigners is not internalized in the regional optimization problem. However, the purchased fraction is internalized because the user fee acts exactly as a mechanism to (imperfectly) internalize the spillover. To make this intuition precise, (24) can be written as

$$
\left(\lambda^{i}-\mu^{i}\right) p_{i}^{i}\left(1-\pi_{i}^{i}\right)-\mu^{i}\left[1+p_{j}^{i}\left(1-\pi_{j}^{i}\right)\right]+\gamma_{i}^{i}+\gamma_{i}^{j}=0 .
$$

Solving (22) and (23) for $\gamma_{i}^{i}$, and $\gamma_{i}^{j}$ yields

$$
\gamma_{i}^{i}=\frac{\left(\mu^{i}-\lambda^{i}\right) p_{i}^{i}}{\varepsilon_{i}^{i}}+\mu^{i} p_{i}^{i}
$$

and

where

$$
\gamma_{j}^{i}=\mu^{i} p_{j}^{i}\left(1+\frac{1}{\varepsilon_{j}^{i}}\right)
$$

$$
\varepsilon_{i}^{i}=\frac{\partial c_{i D}^{i}}{\partial p_{i}^{i}} \frac{p_{i}^{i}}{c_{i D}^{i}}<0, \varepsilon_{j}^{i}=\frac{\partial c_{j D}^{i}}{\partial p_{j}^{i}} \frac{p_{j}^{i}}{c_{j D}^{i}}<0
$$

Using (28) and (29) in (27) yields, after some rearrangements,

$$
1-p_{i}^{i}-p_{j}^{i}=-\frac{\left(\mu^{i}-\lambda^{i}\right)}{\mu^{i}} p_{i}^{i}\left(1-\pi_{i}^{i}-\frac{1}{\varepsilon_{i}^{i}}\right)-\mu^{i} p_{j}^{i}\left(1-\pi_{j}^{i}-\frac{1}{\varepsilon_{j}^{i}}\right)<0,
$$


which implies

$$
\frac{u_{c_{i}^{i}}}{\lambda^{i}}+\frac{u_{c_{i}^{j}}}{\lambda^{j}}>1
$$

It turns out that, despite the possibility of user-fee financing, the spillover good is always underprovided relative to the Samuelson quantity. (30) shows that there are two reasons for this underprovision result. The first term on the r.h.s. of (30) reflects that the marginal source of government revenues is distortionary. This induces the government to distort the supply of the spillover good. The second term on the r.h.s. of (30) reflects that the government of country $i$ does not take into account the effects of providing the spillover good and levying user fees on the utility of foreign citizens.

\subsection{Policy Coordination}

The comparison of first-order conditions of the centralized and the decentralized problem has revealed a complex structure of externalities present in decentralized decision making. Hence, it cannot be expected that the decentralized solution will turn out to be optimal. In order to prove this conjecture and to understand the deviation of the decentralized solution from the centralized one we consider four types of coordinated policy changes in this section,

1. a coordinated marginal increase in the user fee paid by domestic citizens,

2. a coordinated marginal increase in the user fee paid by foreign citizens,

3. a coordinated marginal increase in the exclusion investment directed against foreign free riders,

4. a coordinated marginal increase in the supply of the spillover good.

In all these cases, we assume that the coordination departs from the equilibrium without coordination and that investments in exclusion and user fees are positive in the decentralized equilibrium but that exclusion is not perfect. Moreover, the government budget constraint is balanced by adjusting the supply of $g$. 


\section{Coordination of user fees paid by domestic citizens.}

The welfare effect of a coordinated change in user fees paid by domestic citizens is given by

$$
\frac{d \mathcal{L}^{i d}}{d p_{j}^{j}}=\frac{\partial \mathcal{L}^{i d}}{\partial p_{j}^{j}}=\left(\mu^{i} p_{j}^{i}-\gamma_{j}^{i}\right) \frac{\partial c_{j D}^{i}}{\partial p_{j}^{j}}
$$

The f.o.c. for $p_{i}^{i}$ implies

$$
\mu^{i} p_{j}^{i}-\gamma_{j}^{i}=-\frac{\mu^{i}}{\varepsilon_{j}^{i}} p_{j}^{i}>0
$$

We may thus state

Result 1: If the foreign spillover good is a substitute (complement) for the domestic good, $\partial c_{j D}^{i} / \partial p_{j}^{j}>(<) 0$, a coordinated increase in user fees for domestic citizens increases (reduces) welfare.

Result 1 shows that the strategic incentives for setting user fees on foreigners are determined by the degree of complementarity/substitutability between both regions' spillover goods. An increase in the user fee paid by domestic citizens creates a fiscal externality because demand for the domestic and the foreign spillover goods is interdependent. If the goods are substitutes, the increase in the fee for domestic users induces them to increase their demand for the foreign spillover good, which increases user-fee revenues abroad and therefore raises welfare abroad. The analogy to the capital tax competition literature is obvious. Under the source principle an increase in the tax rate in one region creates a positive externality in the other regions because the reallocation of capital increases foreign tax bases. The problem of tax competition is increasing in the elasticity of capital supply. With user fees the problem is similar if the goods are substitutes. If the goods are complements, however, the externality caused by an increase in user fees is negative because an increase in foreign prices is partly compensated by a decrease in domestic demand. This reduces foreign revenues, and foreign welfare is negatively affected.

\section{Coordination of user fees paid by foreign citizens.}

The intuition given in the last paragraph should in principle also apply for the case of user fees paid by foreign citizens. However, the problem is different because 
contrary to the case of domestic user fees the foreign direct utility effect of an increase in foreign user fees is not internalized by the domestic government.

The welfare effect of a coordinated change in $p_{j}^{i}, p_{i}^{j}$ is given by

$$
d \mathcal{L}^{i d}=\frac{\partial \mathcal{L}^{i d}}{\partial p_{j}^{i}} d p_{j}^{i}+\frac{\partial \mathcal{L}^{i d}}{\partial p_{i}^{j}} d p_{i}^{j}
$$

In the equilibrium without coordination, we have $\frac{\partial \mathcal{L}^{i d}}{\partial p_{j}^{i}}=0$, so that the welfare effect of the coordination agreement is given by

$$
\frac{d \mathcal{L}^{i d}}{d p_{i}^{j}}=\frac{\partial \mathcal{L}^{i d}}{\partial p_{i}^{j}}=-\lambda^{i} c_{i D}^{j}+\left(\mu^{i} p_{i}^{i}-\gamma_{i}^{i}\right) \frac{\partial c_{i D}^{i}}{\partial p_{i}^{j}} .
$$

The f.o.c. for $p_{i}^{i}$ implies

$$
\mu^{i} p_{i}^{i}-\gamma_{i}^{i}=-\frac{\left(\mu^{i}-\lambda^{i}\right)}{\varepsilon_{i}^{i}} p_{i}^{i}>0
$$

We may thus state:

\section{Result 2:}

i) If the domestic spillover good is a complement for the foreign good, $\partial c_{i D}^{i} / \partial p_{i}^{j}<$ 0 , a coordinated increase of the user fee on foreigners reduces welfare.

ii) If the domestic spillover good is a substitute for the foreign good $\partial c_{i D}^{i} / \partial p_{i}^{j}<0$, a coordinated increase of the user fee on foreigners may increase or decrease welfare.

Surprisingly, despite the fact that the domestic government neglects any direct effect on utility (and thereby maximizes revenues when setting user fees) it turns out that a coordinated increase of the user fee for foreign users does not necessarily decrease welfare. This happens because an increase in foreign user fees may raise domestic private demand for the domestic spillover good. The increase in user-fee revenue may increase domestic welfare. If the price elasticity is sufficiently large this revenue effect dominates. 


\section{Coordination of exclusion investments directed against foreign free riders.}

A coordinated change in exclusion investment against foreign free riders has the following welfare effect:

$$
\frac{d \mathcal{L}^{i d}}{d d_{i}^{j}}=\frac{\partial \mathcal{L}^{i d}}{\partial d_{i}^{j}}=-u_{c_{i}^{j}} \pi_{i d}^{j} c_{j S} .
$$

We may thus state

Result 3: A coordinated reduction in exclusion investment against foreign free riders increases welfare.

Result 3 is intuitive. Acting individually rational, regions take into account the benefit from excluding foreigners from the consumption of the domestic spillover good but they do not take into account the costs imposed on foreigners.

There are no effects of changes in investments in exclusion on demand for spillover goods in the other countries. One should note that this property of demand functions is due to the preference structure we have assumed. For more general utility functions, changes in the investments in exclusion will again affect demand for the spillover goods and will, therefore, give rise to fiscal externalities similar to those discussed in the context of Results 1 and 2 .

In a world where user fees can be perfectly enforced without any costs the use of the market mechanism has two very attractive properties. First, the fact that all potential users pay for the use of the goods solves the incentive problem present when the regions non-cooperatively decide how much of the spillover good is to be produced. The fact that user prices reflect marginal rates of substitutions implies that a decentralized planner acts as if he internalizes the utility of the total population. The incentive problem cannot be solved by the use of traditional tax mechanisms because even if foreigners pay domestic taxes their marginal utility of the spillover good would still be neglected in the decentralized decision problem. Second, user fees are appealing because every individual (and thereby every region) pays according to its valuation of the good (principle of correspondence). Tax financ- 
ing without exclusion may imply de-facto interregional subsidies that may provoke political opposition. Hence there cannot be 'too much market' if markets are free.

In a world with costly exclusion, however, user fees lose some of their attractive features. There can and will be 'too much market' if regions invest in exclusion noncooperatively. From the centralized point of view it is rational to allow for a degree of free riding by foreigners that exceeds the decentralized one, which breaks the principle of correspondence. The implied dilution of regional incentives to produce the spillover good is more then compensated by the implied reduction in the costs of exclusion.

\section{Coordination in the supply of the spillover good.}

Finally consider a coordinated change in the supply of the spillover good, holding user fees constant. The welfare effect is

$$
\frac{d \mathcal{L}^{i d}}{d c_{S}}=\frac{\partial \mathcal{L}^{i d}}{\partial c_{S}^{j}}=\left(1-\pi_{i}^{j}\right) u_{c_{i}^{j}}>0 .
$$

Result 4 follows immediately:

Result 4: A coordinated increase in the supply of the spillover good increases welfare.

The result is a consequence of the positive externality created by regional investments in the spillover good. Prima facie, every region neglects the direct utility effect caused by its supply decision in the other region. Part of this externality is internalized by the (endogenously established) price mechanism. However, because the price mechanism is imperfect there remains a positive externality in equilibrium.

\subsection{Perfect substitutes}

In this section we will focus on the extreme case where the two spillover goods are perfect substitutes that has been excluded from our analysis so far. This case allows it to understand the strategic incentives present in the decentralized solution in a very stylized way. 
The utility function of resident $i$ is $u\left(c_{i}^{i}, c_{j}^{i}, x^{i}, g^{i}\right)=m\left(c_{i}^{i}+c_{j}^{i}\right)+x^{i}+h\left(g^{i}\right)$, where $m($.$) is strictly concave. { }^{3}$

In this case, for any given tax rates $t^{i}, t^{j}$, quantities $g^{i}, g^{j}, c_{S}^{i}, c_{S}^{j}$ and $d_{i}^{i}, d_{i}^{j}$, $d_{j}^{i}$, and $d_{j}^{j}$, it is straightforward to show that only user fees $p_{i}^{i}=p_{i}^{j}=p_{j}^{i}=p_{j}^{j}=0$ can be an equilibrium of the decentralized game: assume w.l.o.g. that $p_{j}^{j}>0$. In that case, demand for spillover good $i$ by residents from region $j$ is zero for all $p_{j}^{i}>p_{j}^{j}$, indeterminate for $p_{j}^{i}=p_{j}^{j}$, and equal to $c_{j D}^{i}$ for all $p_{j}^{i}<p_{j}^{j}$. Hence, demand is discontinuous at $p_{j}^{i}=p_{j}^{j}$. In order to maximize revenues from foreign consumption (equation (23)) it is always rational to set $p_{j}^{i}=p_{j}^{j}-\epsilon, \epsilon>0, \epsilon \rightarrow 0$. By the same token it is evident that country $j$ 's optimal reaction is to undercut every positive price of the other country as well, because otherwise its revenues would be zero anyway. ${ }^{4}$

Given that user fees are equal to zero irrespective of the other policy variables, it follows immediately that the optimal investments in defense, (25) and (26), are equal to zero as well: the only reason to exclude consumers from free riding is to raise revenues for the financing of the spillover good. If this is not possible it makes no sense to waste resources on exclusion.

Result 5: If both spillover goods are perfect substitutes there will be no exclusion in the decentralized equilibrium and the user fees will all be equal to zero.

There is again a close analogy between Result 5 and the literature on capitaltax competition: If the source principle applies, capital-tax competition between two small countries drives capital taxes to zero because of the infinite elasticity of capital supply. If the spillover goods are perfect substitutes the elasticity of demand is also infinite, implying that small differences in user fees induce a complete interregional reallocation of demand.

\footnotetext{
${ }^{3}$ In order to avoid notational clutter we use the same symbol for $m\left(c_{i}^{i}, c_{j}^{i}\right)$ and $m\left(c_{i}^{i}+c_{j}^{i}\right)$.

${ }^{4}$ Zero user fees play the role of the "price equals marginal costs" rule in the Bertrand oligopoly model.
} 


\section{Conclusions}

This paper has set a framework for thinking about the relationship between tax and user-fee financing of decentrally provided spillover goods. We have shown that decentralized policies cause a number of externalities that lead to over-investment in exclusion and the strategic setting of fees. Hence, economic integration is likely to cause problems for price mechanisms which are similar to those faced by tax mechanisms. A shift towards user-fee financing of publicly provided goods is therefore no way out of the problem of tax competition. However, countries engaging in user-fee competition may end up with inefficiently low or inefficiently high levels of user fees, depending on whether the spillover goods are substitutes or complements.

Given the recent trend towards user fees in many countries, our findings have important policy implications. First of all it cannot be expected that regions have an incentive to efficiently invest in exclusion technologies. On the contrary it can be expected that 'over-enforcement' will occur, that there is 'too much market' in equilibrium because regional governments neglect the foreign free-rider utility. Second, it cannot be expected that regional governments set user-fees efficiently.

If the spillover goods are substitutes our analysis predicts that countries will engage in a race to the bottom because an increase (reduction) in user fees creates a positive (negative) externality in the other region. Hence, countries can increase their user-fee revenues by lowering their user fees and thereby attracting foreign users. Examples for spillover goods that are substitutes are university education, where different regions compete for students, state-owned national parks, museums, or concert halls, were different regions compete for tourists or visitors, or regions that are located to each other such that the user can choose between both road systems when travelling from A to B.

If the spillover goods are complements our analysis predicts that countries will engage in a race to the top. An increase (decrease) in the user fee creates a negative (positive) externality in the other region because any reduction in the domestic demand for spillover goods is accompanied by a reduction in the demand for foreign spillover goods. As a consequence user fees tend to be inefficiently high. The highway 
systems of two regions a user has to cross when travelling from A to B is an example for this case.

Our analysis suggests that the decentralized setting of user fees is likely to be inefficient. The implication of this finding is, however, not that political responsibilities for user fees have to be centralized. It is an important lesson from the theory of tax competition that inefficiencies of decentralized decision making depend on the tax principles applied. It is not the decentralized responsibility for taxation but the source principle that causes the problem. A switch towards a destination principle would eliminate any strategic incentive as long as households are immobile and a system of information exchange can be established. The same logic applies to the case of user-fee competition. In this paper we have implicitly assumed that a 'destination' principle applies in the sense that users have to pay fees according to the principles of the country who provides the good. This principle creates strategic incentives because, e.g. in the case of substitutes individuals can avoid high fees by using the spillover good of an alternative country. Switching towards a "nationality' principle where the regional government sets user fees for its residents for all competing spillover goods eliminates strategic incentives if the regions commit to a system of information exchange about the foreign use of spillover goods. In this case regional governments have no incentive to engage in user-fee competition because increasing or lowering fees does not create an externality in the other region. However, despite the fact that this system eliminates strategic incentives in setting user fees, it does not eliminate the problem of underprovision of the spillover good as long as it is not accompanied by a system of inter-regional transfers.

There are a number of interesting extensions to our analysis, and we will briefly discuss two of them. First, our analysis has assumed that user fees can be set as to discriminate between domestic and foreign users. This may be a realistic assumption for some goods (tuition fees usually discriminate between domestic and foreign students), but for practical or principle reasons not so realistic for other goods. For example entrance fees to national parks, museums or concert halls usually do not differentiate according to nationality. The European Union Directive 99/62/EC explicitly prohibits discrimination for the case of road pricing. However, the principle 
structure of externalities would remain intact if the governments had to set a uniform user fee because national authorities would still fail to internalize the direct effect of their policies on foreign welfare. Hence, the voluntary co-operation of Belgium, Denmark, Luxembourg, the Netherlands, and Sweden to introduce a common system of user fees (the so called 'Eurovignette') may be a means to overcome the inefficiencies of a decentralized solution. ${ }^{5}$

Second we have abstracted from another important reason why user-fee financing has become popular in the last couple of years. It is not only a means to raise government revenues but also a means to internalize externalities if the spillover goods suffer from congestion. The incentive effect of time-dependent highway-toll systems in metropolitan areas like Singapore or London is at least as important as the revenue effect. It is unclear how our results carry over to the case of spillover goods with congestion but we think that the strategic effects isolated by the analysis of the present paper should have an influence on the incentives to set user fees in case of congestion.

\section{References}

- Bond, E.W. and L. Samuelson (1989): Strategic Behavior and the Rules for International Taxation of Capital, Economic Journal 99, 1099-1111.

- Brito, D.L. and W.H. Oakland (1980): "On the Monopolistic Provision of Excludable Public Goods," American Economic Review 70, 691-704.

- Bucovetsky, S. (1991): “Asymmetric Tax Competition," Journal of Urban Economics 30, 167-181.

- Bucovetsky, S. and J. Wilson (1991): Tax Competition with Two Instruments," Regional Science and Urban Economics 21, 333-350.

\footnotetext{
${ }^{5}$ See http://europa.eu.int/comm/transport/road/policy/roadcharging/tolls/index_en.htm for further information about the European transport policy.
} 
- Clotfelter, C.T. (1977): "Public Services, Private Substitutes, and the Demand for Protection against Crime," American Economic Review 67, 867-877.

- Clotfelter, C.T. (1978): "Private Security and the Public Safety," Journal of Urban Economics 5, 388-402.

- Fraser, C.D. (1996): "On the Provision of Excludable Public Goods," Journal of Public Economics 60, 111-130.

- Fuest, C. B. Huber and J. Mintz (2003): Capital Mobility and Tax Competition: A Survey, CESifo Discussion paper No. 956, May2003.

- Janeba, E. and G. Schjelderup (2002): "Tax Competition: A Review of the Theory," http://odin.dep.no/ud/norsk/handelspolitikk/032121220006/index-dok000-b-f-a.html

- Janeba, E. and K.J. Swope (2001): "Taxes or Fees? The Political Economy of Providing Excludable Public Goods," Mimeo, University of Colorado.

- Laux-Mieselbach, W. (1988): "Impossibility of Exclusion and Characteristics of Public Goods," Journal of Public Economics 36, 127-137.

- Polinsky, A.M. and S. Shavell (2000): "The Economic Theory of Public Enforcement of Law," Journal of Economic Literature 38, 45-76.

- Sinn, H.W. (2003): "The New Systems Competition," Oxford: Blackwell Publishing.

- Wilson, J. (1986): “A Theory of Interregional Tax Competition, Journal of Urban Economics 19, 296-315.

- Wilson, J.D. (1991): "Tax Competition with Interregional Differences in Factor Endowments," Regional Science and Urban Economics 21, 423-451.

- Wilson, J.D. (1999): “Theories of Tax Competition," National Tax Journal 52, 269-304. 


\section{CESifo Working Paper Series}

(for full list see www.cesifo.de)

1101 Lawrence M. Kahn, Sports League Expansion and Economic Efficiency: Monopoly Can Enhance Consumer Welfare, December 2003

1102 Laszlo Goerke and Wolfgang Eggert, Fiscal Policy, Economic Integration and Unemployment, December 2003

1103 Nzinga Broussard, Ralph Chami and Gregory D. Hess, (Why) Do Self-Employed Parents Have More Children?, December 2003

1104 Christian Schultz, Information, Polarization and Delegation in Democracy, December 2003

1105 Daniel Haile, Abdolkarim Sadrieh and Harrie A. A. Verbon, Self-Serving Dictators and Economic Growth, December 2003

1106 Panu Poutvaara and Tuomas Takalo, Candidate Quality, December 2003

1107 Peter Friedrich, Joanna Gwiazda and Chang Woon Nam, Development of Local Public Finance in Europe, December 2003

1108 Silke Uebelmesser, Harmonisation of Old-Age Security Within the European Union, December 2003

1109 Stephen Nickell, Employment and Taxes, December 2003

1110 Stephan Sauer and Jan-Egbert Sturm, Using Taylor Rules to Understand ECB Monetary Policy, December 2003

1111 Sascha O. Becker and Mathias Hoffmann, Intra-and International Risk-Sharing in the Short Run and the Long Run, December 2003

1112 George W. Evans and Seppo Honkapohja, The E-Correspondence Principle, January 2004

1113 Volker Nitsch, Have a Break, Have a ... National Currency: When Do Monetary Unions Fall Apart?, January 2004

1114 Panu Poutvaara, Educating Europe, January 2004

1115 Torsten Persson, Gerard Roland, and Guido Tabellini, How Do Electoral Rules Shape Party Structures, Government Coalitions, and Economic Policies? January 2004

1116 Florian Baumann, Volker Meier, and Martin Werding, Transferable Ageing Provisions in Individual Health Insurance Contracts, January 2004 
1117 Gianmarco I.P. Ottaviano and Giovanni Peri, The Economic Value of Cultural Diversity: Evidence from US Cities, January 2004

1118 Thorvaldur Gylfason, Monetary and Fiscal Management, Finance, and Growth, January 2004

1119 Hans Degryse and Steven Ongena, The Impact of Competition on Bank Orientation and Specialization, January 2004

1120 Piotr Wdowinski, Determinants of Country Beta Risk in Poland, January 2004

1121 Margarita Katsimi and Thomas Moutos, Inequality and Redistribution via the Public Provision of Private Goods, January 2004

1122 Martin Peitz and Patrick Waelbroeck, The Effect of Internet Piracy on CD Sales: CrossSection Evidence, January 2004

1123 Ansgar Belke and Friedrich Schneider, Privatization in Austria: Some Theoretical Reasons and First Results About the Privatization Proceeds, January 2004

1124 Chang Woon Nam and Doina Maria Radulescu, Does Debt Maturity Matter for Investment Decisions?, February 2004

1125 Tomer Blumkin and Efraim Sadka, Minimum Wage with Optimal Income Taxation, February 2004

1126 David Parker, The UK's Privatisation Experiment: The Passage of Time Permits a Sober Assessment, February 2004

1127 Henrik Christoffersen and Martin Paldam, Privatization in Denmark, 1980-2002, February 2004

1128 Gregory S. Amacher, Erkki Koskela and Markku Ollikainen, Deforestation, Production Intensity and Land Use under Insecure Property Rights, February 2004

1129 Yin-Wong Cheung, Javier Gardeazabal, and Jesús Vázquez, Exchange Rate Dynamics: Where is the Saddle Path?, February 2004

1130 Alberto Alesina and Guido Tabellini, Bureaucrats or Politicians?, February 2004

1131 Gregory S. Amacher, Erkki Koskela, and Markku Ollikainen, Socially Optimal Royalty Design and Illegal Logging under Alternative Penalty Schemes, February 2004

1132 David M. Newbery, Privatising Network Industries, February 2004

1133 Charles Yuji Horioka, The Stagnation of Household Consumption in Japan, February 2004

1134 Eiji Fujii, Exchange Rate Pass-Through in the Deflationary Japan: How Effective is the Yen's Depreciation for Fighting Deflation?, February 2004 
1135 Mark M. Spiegel and Nobuyoshi Yamori, Determinants of Voluntary Bank Disclosure: Evidence from Japanese Shinkin Banks, Febrary 2004

1136 Robert Dekle and Kenneth Kletzer, Deposit Insurance, Regulatory Forbearance and Economic Growth: Implications for the Japanese Banking Crisis, February 2004

1137 Takatoshi Ito and Kimie Harada, Bank Fragility in Japan, 1995-2003, February 2004

1138 Kunio Okina and Shigenori Shiratsuka, Policy Duration Effect under Zero Interest Rates: An Application of Wavelet Analysis, February 2004

1139 Francine D. Blau and Lawrence M. Kahn, Do Cognitive Test Scores Explain Higher U.S. Wage Inequality?, February 2004

1140 Michael Rauscher, Economic Growth and Tax-Competing Leviathans, February 2004

1141 Ernst Fehr and Jean-Robert Tyran, Money Illusion and Coordination Failure, February 2004

1142 Ingo Vogelsang, Network Utilities in the U.S. - Sector Reforms without Privatization, March 2004

1143 Marc-Andreas Muendler, Estimating Production Functions When Productivity Change is Endogenous, March 2004

1144 Sascha O. Becker, Samuel Bentolila, Ana Fernandes, and Andrea Ichino, Job Insecurity and Children's Emancipation, March 2004

1145 Pascalis Raimondos-Møller and Alan D. Woodland, Non-Preferential Trading Clubs, March 2004

1146 Robert Fenge and Matthias Wrede, EU Regional Policy: Vertical Fiscal Externalities and Matching Grants, March 2004

1147 Chi-Yung Ng and John Whalley, Geographical Extension of Free Trade Zones as Trade Liberalization: A Numerical Simulation Approach, March 2004

1148 Marc-Andreas Muendler, Trade, Technology, and Productivity: A Study of Brazilian Manufacturers, 1986-1998, March 2004

1149 Eugene Beaulieu, Vivek H. Dehejia, and Hazrat-Omar Zakhilwal, International Trade, Labour Turnover, and the Wage Premium: Testing the Bhagwati-Dehejia Hypothesis for Canada, March 2004

1150 Giorgio Brunello and Francesca Gambarotto, Agglomeration Effects on EmployerProvided Training: Evidence from the UK, March 2004

1151 S. Brock Blomberg, Gregory D. Hess, and Athanasios Orphanides, The Macroeconomic Consequences of Terrorism, March 2004 
1152 Bodo Sturm and Joachim Weimann, Unilateral Emissions Abatement: An Experiment, March 2004

1153 Wolfgang Ochel, Welfare-to-Work Experiences with Specific Work-First Programmes in Selected Countries, March 2004

1154 Jan K. Brueckner and Eric Pels, European Airline Mergers, Alliance Consolidation, and Consumer Welfare, March 2004

1155 Aaron Tornell, Frank Westermann, and Lorenza Martínez, NAFTA and Mexico's Economic Performance, March 2004

1156 George Economides, Sarantis Kalyvitis, and Apostolis Philippopoulos, Do Foreign Aid Transfers Distort Incentives and Hurt Growth? Theory and Evidence from 75 Aidrecipient Countries, March 2004

1157 Robert Fenge and Volker Meier, Are Family Allowances and Fertility-related pensions Siamese Twins?, March 2004

1158 Bruno S. Frey, Simon Luechinger, and Alois Stutzer, Valuing Public Goods: The Life Satisfation Approach, March 2004

1159 Jerome L. Stein and Guay C. Lim, Asian Crises: Theory, Evidence, Warning-Signals, March 2004

1160 Romain Ranciere, Aaron Tornell, and Frank Westermann, Crises and Growth: A ReEvaluation, March 2004

1161 Assaf Razin and Efraim Sadka, Transparency, Specialization and FDI, March 2004

1162 Ludger Woessmann, How Equal Are Educational Opportunities? Family Background and Student Achievement in Europe and the United States, March 2004

1163 B.M.S. van Praag and Barbara E. Baarsma, Using Happiness Surveys to Value Intangibles: The Case of Airport Noise, March 2004

1164 Aaron Tornell, Frank Westermann, and Lorenza Martínez, The Positive Link Between Financial Liberalization, Growth, and Crises, March 2004

1165 Helge Berger and Carsten Hefeker, One Country, One Vote? Labor Market Structure and Voting Rights in the ECB, March 2004

1166 Clemens Fuest and Martin Kolmar, A Theory of User-Fee Competition, March 2004 